\author{
Monika Plaziak \\ Uniewersytet Pedagogiczny \\ im. Komisji Edukacji Narodowej \\ w Krakowie
}

\title{
Technologia tanich domów energooszczędnych jako odpowiedź na kryzys w budownictwie mieszkaniowym
}

\author{
Technology of constructing cheap, energy-efficient house as an answer \\ to the housing ind ustry crisis
}

\begin{abstract}
Streszczenie
Na tle kryzysu gospodarczego, ujawniającego się m.in. w budownictwie mieszkaniowym oraz rosnących kosztach utrzymania mieszkań, zwłaszcza ze względu na rosnące ceny nośników energii oraz $\mathrm{w}$ aspekcie relatywnie niskiego standardu mieszkaniowego w Polsce, w artykule omówiono przykład innowacyjnych poszukiwań w zakresie taniego budownictwa. Technologia budowy domów ze spienionego polistyrenu (zwanego neoporem) jest próbą wyjścia naprzeciw zapotrzebowaniu deweloperów i użytkowników na domy tanie w budowie, a jednocześnie zgodne ze współczesnymi trendami, a więc odpowiadające wymogom energooszczędności i pasywności. Jest to przykład nowatorskiego myślenia, opierającego się nie na udoskonalaniu istniejących, lecz na wprowadzaniu nowych metod budowlanych, polegających na wykorzystywaniu materiału dotychczas używanego w celach izolacyjnych do celów odmiennych - konstrukcyjnych. Omówiona w artykule metoda nie pozostaje pomysłem na papierze, ale znajduje zastosowanie w praktyce; istnieją już budynki powstałe w tej technologii, których wzniesienie wygenerowało znaczne korzyści w porównaniu z budową domów tradycyjnych. W przyszłości należy spodziewać się większej liczby podobnych przedsięwzięć, zrodzonych z zapotrzebowania na oszczędności w dobie kryzysu, świadczących zarazem o potencjale innowacyjnym polskich środowisk inżynierskich. Oczywiście muszą zostać pokonane pewne bariery mentalne, zwłaszcza dotyczące oporów przed mieszkaniem „w styropianie”, a także wymagana jest pewna elastyczność przyszłych użytkowników domów z neoporu. Zaprezentowane w artykule korzyści płynące z potencjalnego zastosowania nowatorskiej technologii z pewnością zadecydują o jej wdrożeniu. Niebagatelne znaczenie w przyszłości będzie miało wspieranie tego rodzaju inicjatyw przedsiębiorców przez środowiska naukowe i badawczo-rozwojowe, polegające głównie na ocenie i testowaniu nowych materiałów oraz technologii.
\end{abstract}

\begin{abstract}
The following paper discusses research, connected with innovative solutions in the field of cheap housing construction, relating to the economic crisis, noticeable also in the housing industry, in the form of rising costs of dwelling usage, due mostly to increasing prices of energy, in the aspect of the relatively low standard of housing in Poland. The technology of design and construction of buildings from frothed polystyrene ('neopor'), presented in the following article, is an example of meeting the expectations of developers and dwelling users, by building houses which are less expensive to construct and maintain, in accordance with the requirements of energy-efficiency and passivity.
\end{abstract}


The above is an example of innovative thinking, based not on improvements to existing building methods, but on the implementation of new solutions, which take advantage of modern materials (neopor), heretofore used only for purposes of insulation, and now being employed as a construction material. The method described in this article is not only a theoretical idea, but one that is being currently realized, in the form of buildings constructed from prefabricated neopor elements in the Małopolska region. Erecting these buildings, using the above-mentioned method, was cheaper and faster, compared to the traditional manner. Similar undertakings should be expected in the future, due to demand for low-cost housing in the period of crisis, and as an expression of the innovative potential of Polish engineers. Of course, such innovative solutions require the breaking of certain barriers of stereotypical thinking, connected with 'living in polystyryne foam', as well as a dose of flexibility from users of future neopor houses. However, benefits of applying such an innovative technology, presented in the article, will certainly lead to its implementation. In the future, the most important issue seems to be the development of cooperation between scientists and entrepreneurs, especially in the areas of tests and evaluations of new materials and technologies.

Slowa kluczowe: domy energooszczędne i pasywne; kryzys gospodarczy

Key words: energy-efficient and passive houses; economic crisis

\section{Wprowadzenie}

W niniejszym opracowaniu zaprezentowano innowacyjną technologię budowy domów, które mogą być wznoszone w postaci budynków energooszczędnych i pasywnych. Jest to rozwiązanie unikatowe w skali światowej, zważywszy zwłaszcza na aspekt oszczędnościowy kosztów i czasu budowy. Zasadniczym celem artykułu jest zasygnalizowanie konieczności poszukiwania tego rodzaju rozwiązań w związku ze stwierdzonym kryzysem w branży budownictwa mieszkaniowego, a więc zakładanymi niższymi funduszami na inwestycje mieszkaniowe w przyszłości, jak również wymaganiami określonymi w dyrektywie unijnej dotyczącej obowiązku krajów członkowskich do wznoszenia nowych budynków do roku 2020 wyłącznie w standardzie „niemal zeroenergetycznym”, który aktualnie w warunkach polskich wymaga przynajmniej kilkunastoprocentowych suplementarnych kosztów budowy. Jak wskazują zamieszczone w niniejszym opracowaniu analizy kosztów budowy wzniesionych domów energooszczędnych i pasywnych na świecie i w Polsce, każdorazowa budowa dokonana w takim standardzie generowała dotychczas wyższe nakłady finansowe, w porównaniu z budową domu tradycyjnego. W związku ze wspomnianą dyrektywą unijną stosowanie popularnych technologii budowy do wznoszenia domów zgodnych z wymogami dyrektywy wiązać się będzie z wyższymi niż obecnie kosztami budowy, a co za tym idzie - z pogłębieniem kryzysu w zakresie budownictwa mieszkaniowego. Jedyną alternatywą uniknięcia takiego scenariusza staje się poszukiwanie nowych rozwiązań, odpowiadających wymogom budownictwa zgodnego z wytycznymi unijnymi przy jednoczesnym spadku kosztów budowy. Jednocześnie istotnym przedsięwzięciem winno być rozbudowywanie i upowszechnianie bazy laboratoriów testowania nowych rozwiązań. Utrudniona dostępność do tego rodzaju ośrodków i wysokie koszty badań stanowią, zdaniem konstruktorów i architektów, wyraźną barierę wdrażania nowych technologii w zakresie budownictwa niskoenergetycznego.

\section{Pytanie o kryzys w budownictwie}

Przyjmując za podstawę dane statystyczne GUS dotyczące produkcji montażowo-budowlanej w ostatnich latach, nie możemy jednoznacznie wnioskować o kryzysie w całości branży budowlanej. W latach 2005-2011 ogólna produkcja budowlano-montażowa w Polsce 
wykazywała charakter wzrostowy, co opisuje wskaźnik wartości sprzedaży tej produkcji na 1 mieszkańca (ryc. 1). W pierwszej połowie 2012 r. (I-V) produkcja ta była nieco wyższa niż dla roku poprzedniego. O ile okres VI-VIII 2012 r. przyniósł niższą produkcję niż analogiczny okres roku 2011, o tyle sytuacja w sierpniu 2012 r. poprawiła się w stosunku do wcześniejszego miesiąca (ryc. 2).

Ryc. 1. Sprzedaż produkcji budowlano-montażowej w Polsce w latach 2005-2011 przypadająca na 1 mieszkańca

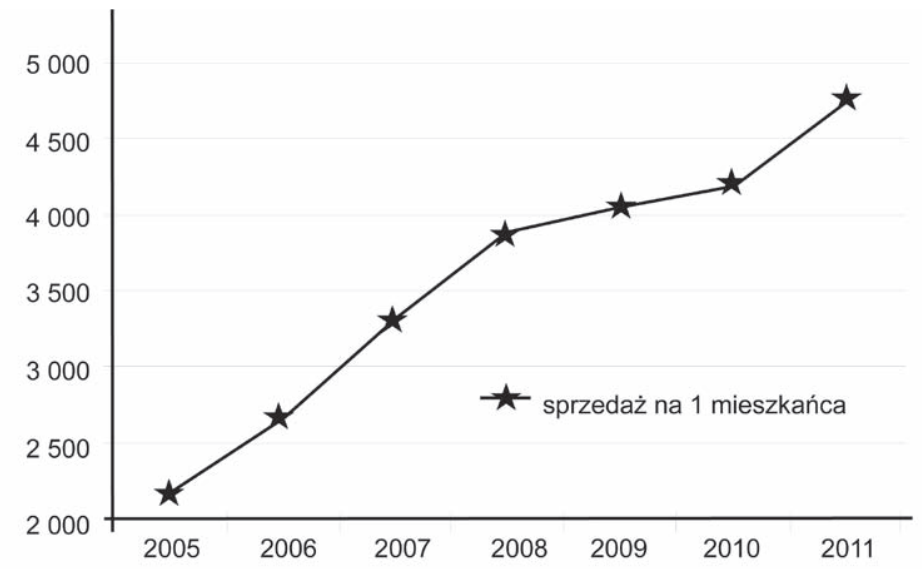

Źródło: opracowanie własne na podstawie danych GUS.

Ryc. 2. Miesięczna dynamika produkcji budowlano-montażowej w Polsce w latach 2008-2012

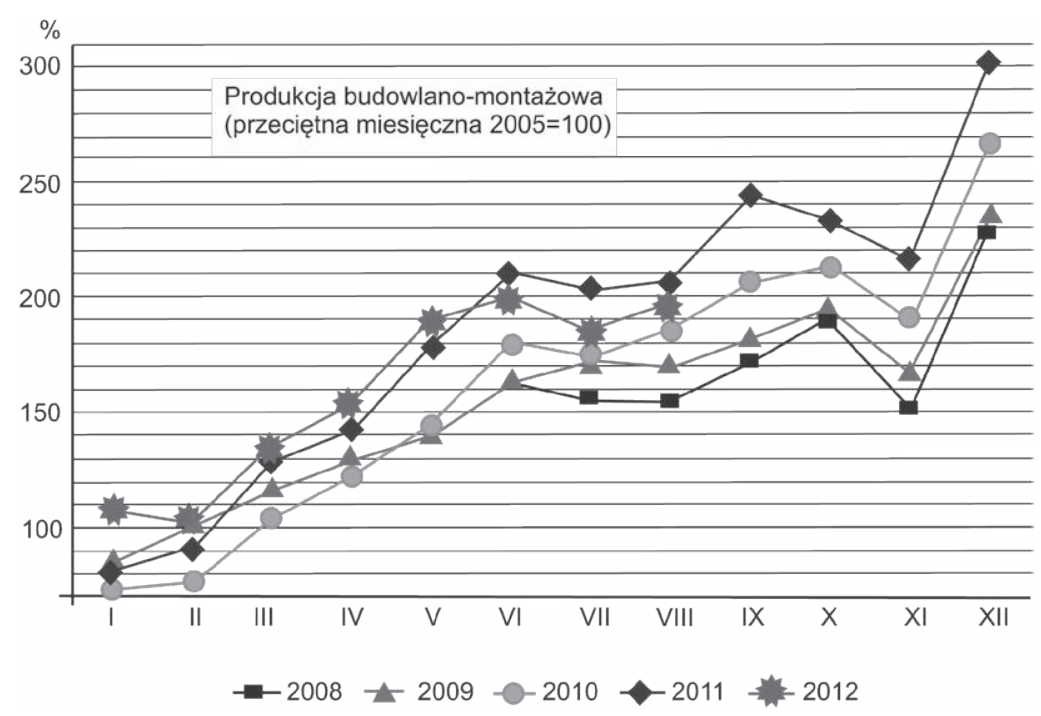

Źródło: GUS (2012). 
Biorąc jednak pod uwagę szczegółową produkcję budowlano-montażową za okres VIII 2011-VIII 2012, należy odnotować znaczny spadek produkcji w dwóch obszarach: produkcji firm budowlanych specjalizujących się we wznoszeniu budynków $(-13,2 \%)$ oraz produkcji firm wykonujących specjalistyczne roboty budowlane $(-6,3 \%)$. Natomiast firmy budowlane realizujące kontrakty w obszarze inżynierii lądowej i wodnej odnotowały wzrost produkcji $(+4,6 \%)$ (tab. 1). Ponadto, od 2005 r. notuje się systematyczny wzrost udziału zamówień publicznych w sferze budowlanej w ogólnej liczbie i wartości zamówień publicznych (Kozik, Starzyk, 2011).

Tab. 1. Dynamika produkcji budowlanej w okresie VIII 2011-VIII 2012

\begin{tabular}{|l|c|}
\hline Wznoszenie budynków & $-13,2 \%$ \\
\hline Specjalistyczne roboty budowlane & $-6,3 \%$ \\
\hline Kontrakty w obszarze inżynierii lądowej i wodnej & $+4,6 \%$ \\
\hline
\end{tabular}

Źródło: GUS (2012).

Całościowa produkcja budowlano-montażowa w okresie I-VIII 2012 r. była o 3,8\% wyższa niż w analogicznym okresie wcześniejszego roku. Jednakże należy pamiętać, że osiągnięte wyniki są konsekwencją wcześniej podpisanych kontraktów, w tym związanych z organizacją Mistrzostw Europy w Piłce Nożnej Euro 2012. Definiując kryzys ekonomiczny, za Encyklopedia $P W N$, jako ,gwałtowne zmniejszenie się aktywności gospodarczej (produkcji, zatrudnienia, inwestycji)", nie możemy wnioskować o kryzysie sięgającym całości produkcji budowlanej, ale z pewnością wspomniana powyżej ujemna dynamika produkcji dotycząca wznoszenia budynków oraz odnotowany po 2008 r. systematyczny spadek powierzchni mieszkań oddanych do użytkowania (ryc. 3), uzasadniają stwierdzenie kryzysu w budownictwie mieszkaniowym.

Kryzys gospodarczy do Polski dotarł z pewnym opóźnieniem w stosunku do jego obszaru źródłowego, czyli Stanów Zjednoczonych, a jego pierwsze przejawy uwidoczniły się w II kwartale 2008 r. (Rachwał, 2011). Budownictwo jest branżą niezwykle wrażliwą, dlatego ujawnienie się w niej znamion kryzysu w ramach niektórych rodzajów produkcji budowlanej nastąpiło relatywnie szybko (Gorzelak, 2009). Stąd też spadek w powierzchni mieszkań oddanych do użytkowania notowano już w 2009 r. (ryc. 3). Dobrym miernikiem kondycji budownictwa mieszkaniowego jest liczba wydawanych pozwoleń na budowę mieszkań. O ile w roku 2012 zanotowano, pierwszy po 2008 r., wzrost powierzchni mieszkań oddanej do użytkowania, o tyle w tym samym roku liczba pozwoleń na budowę mieszkań w nowych budynkach spadła (ryc. 4), co jest przejawem niepokojącym i potwierdzającym tendencję kryzysową w budownictwie mieszkaniowym Polski. Do tego faktu należy dołączyć kolejny - spadek liczby mieszkań sprzedanych, zachodzący pomimo obniżki cen mieszkań (źródło informacji: REAS). Mimo że na rynku oferta mieszkań nadal jest duża, deweloperzy przewidują jej uszczuplenie jako efekt obniżenia siły nabywczej potencjalnych klientów i spadku wolumenu kredytów udzielanych przez banki na zakup mieszkań. 
Ryc. 3. Powierzchnia mieszkań oddanych do użytkowania w Polsce w latach 2005-2011

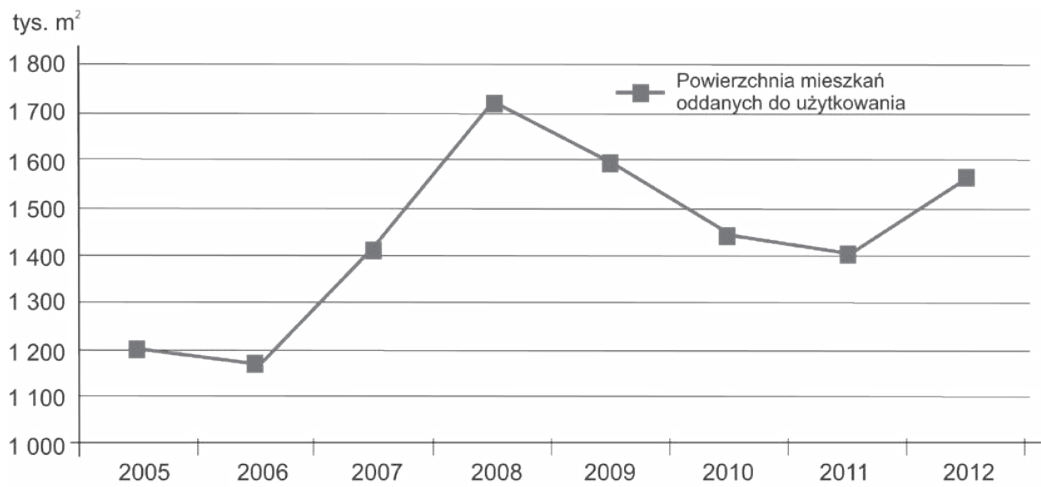

Źródło: opracowanie własne na podstawie danych GUS.

Ryc. 4. Liczba pozwoleń wydanych na budowę mieszkań w nowych budynkach mieszkalnych w Polsce w latach 2005-2012

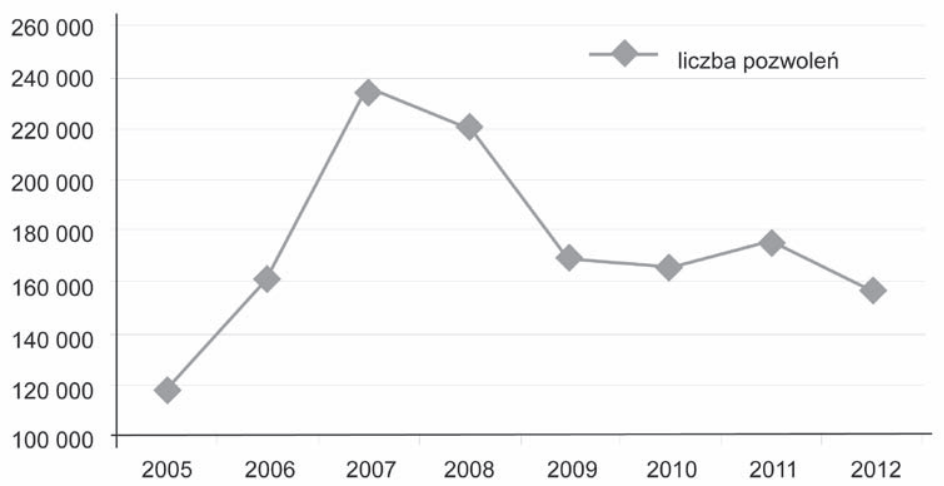

Źródło: opracowanie własne na podstawie danych GUS.

Na powyżej nakreśloną pogarszającą się sytuację produkcji i sprzedaży w budownictwie mieszkaniowym nakłada się relatywnie niski standard mieszkaniowy w Polsce, wyrażony przykładowo liczbą mieszkań przypadającą na 1000 osób. Wskaźnik ten dla Polski wynosi 348, podczas gdy dla większości krajów Europy Zachodniej ponad 500. Zbliżoną, a nawet wyższą wartość wskaźnika od tej aktualnej w Polsce, w krajach Europy Zachodniej stwierdzono już w latach 50. i 60. XX w. Polskie mieszkania są mniejsze i przeludnione, szacuje się, że w przeludnionych mieszkaniach żyje ponad 50\% ludności - gorszy wskaźnik spośród EU27 mają jedynie Węgry i Rumunia, przy średniej dla wszystkich państw unijnych wynoszącej niespełna 18\% (Housing Europe Review, 2011).

Kolejnym aspektem kryzysu w budownictwie mieszkaniowym są rosnące koszty utrzymania budynków, wyrażające się przede wszystkim rosnącymi kosztami energii służącej do ogrzewania mieszkań. Według danych GUS ceny użytkowania mieszkania i nośników energii tylko w okresie IX 2011-IX 2012 wzrosły o 5,5\%, w tym nośników energii o 6,4\%. 
Budownictwo mieszkaniowe stoi przed poważnym problemem wyjścia naprzeciw trudnościom związanym z malejącym popytem na mieszkania ze względu na ogólny kryzys gospodarczy, jak też z utrwalonymi, niższymi od unijnych, warunkami mieszkaniowymi w Polsce. W niniejszym opracowaniu autorka abstrahuje od rozwiązań politycznych, czyli na ile konieczna jest i jaką formę powinna przyjmować ingerencja państwa w rozwiązywanie problemów mieszkaniowych Polaków, ale podaje przykład skutecznej próby radzenia sobie z zaistniałą sytuacją i przetrwania na trudnym rynku mieszkaniowym przez firmy związane z branżą budowlaną. Wydaje się, że niebagatelnym sposobem radzenia sobie z kryzysem w budownictwie mieszkaniowym przez firmy budowlane powinno być poszukiwanie tańszych rozwiązań procesu budowlanego i niższych kosztów eksploatacji budynków.

\section{Czy dom energooszczędny może być tani w budowie?}

W krajach Europy Zachodniej coraz popularniejsza staje się technologia produkcji budynków energooszczędnych, dająca w dłuższej perspektywie czasowej użytkowania takich domów znaczne oszczędności w zakresie użytkowania energii elektrycznej oraz eksploatacji środowiska przyrodniczego. Przyjęło się, iż cena wybudowania takiego obiektu musi być wyższa niż cena obiektu powstającego w tradycyjnej technologii. Ponadto, cena ta rośnie wraz ze stopniem energooszczędności budynku. Jednakże po pewnym czasie dodatkowo poniesione koszty zwracają się, o czym szczegółowiej informuje dalsza część opracowania.

Również na gruncie polskim znane są już i popularyzowane budynki energooszczędne. Za budynek energooszczędny uznaje się zasadniczo taki, który zużywa 25-50\% mniej energii niż budynek tradycyjny, spełniający wymagania nowych warunków technicznych, obowiązujących od 1 stycznia 2009 r. (Rozporządzenie... Dz.U. nr 201, poz. 1238 z późn. zm.). Jak dotąd energooszczędność budynku nie jest prawnie określona, a wynika z zapotrzebowania i jest dynamiczna w związku z postępem techniki i coraz większymi wymaganiami użytkowników. Obecnie w Polsce wskaźnik zapotrzebowania ciepła na ogrzewanie budynku mieszkalnego wybudowanego zgodnie z aktualnymi przepisami budowlanymi wynosi ok. 65-125 kWh/m² powierzchni użytkowej na rok. Budynek energooszczędny powinien na cele ogrzewania, wentylacji i przygotowania ciepłej wody zużywać nie więcej niż 50-70 kWh/m² na rok (Kasperkiewicz, 2005).

Jak wcześniej wspomniano, wzniesienie budynku energooszczędnego od podstaw wymaga poniesienia dodatkowych kosztów w porównaniu z budową domu tradycyjnego, wynikających ze specjalnych wymogów i rozwiązań technicznych. Należą do nich:

- usytuowanie budynku z uwzględnieniem odpowiedniej rzeźby terenu, nasłonecznienia, kierunku wiatrów i osłony zielenią;

- forma budynku maksymalnie zwarta, bez występów i uskoków, pomieszczenia z dużymi oknami od strony południowej, małe okna lub ich brak od strony północnej, buforowe strefy ciepła (cieplarnie, przedsionki, okna słoneczne itp.);

- przegrody zewnętrzne (ściany, dach i stropodach) bardzo dobrze izolowane termicznie, z minimalną ilością mostków termicznych i szczelne;

- okna i drzwi zewnętrzne o wysokiej szczelności i izolacyjności termicznej;

- nocna izolacja okien (okiennice);

- konstrukcja budynku eliminująca większość mostków termicznych;

- balkony o specjalnej konstrukcji ograniczającej do minimum mostki termiczne;

- wentylacja automatycznie regulowana z odzyskiem ciepła;

- $\quad$ system grzewczy i system zaopatrzenia w wodę o bardzo dużej sprawności;

- zalecane wykorzystanie kolektorów słonecznych do przygotowania ciepłej wody użytkowej. 
Dom energooszczędny wymaga także pewnych obostrzeń na etapie projektowania i procesu budowy, czyli:

- dobrego projektu, w którym podane zostaną wszystkie szczegóły wykonania elementów, pozwalających na ograniczenie strat energetycznych;

- właściwej realizacji budowy, zgodnie z projektem, próby szczelności i badania rewizyjnego przegród zewnętrznych.

Powyżej wymieniono najważniejsze wymogi związane z budową domów energooszczędnych, w celu podkreślenia konieczności poniesienia dodatkowych, często wysokich kosztów, jak też zwrócenia uwagi na wynikające z energooszczędności ograniczenia w formie, usytuowaniu i użytkowaniu takich budynków, co może stanowić barierę w rozpowszechnianiu tego rodzaju budownictwa, który to problem poruszono w dalszych partiach niniejszego opracowania.

Wybitnym przykładem domu energooszczędnego jest dom pasywny, niemal całkowicie eliminujący zużycie energii do ogrzewania, zaledwie do $15 \mathrm{kWh} / \mathrm{m}^{2}$ na rok, w którym komfort cieplny zapewniony zostaje dzięki wykorzystaniu pasywnych źródeł ciepła, tj. pochodzących od mieszkańców, urządzeń elektrycznych i promieniowania słonecznego oraz dzięki radykalnemu zmniejszeniu strat ciepła związanego z przenikaniem przez ściany i na wentylację (odzysk ciepła w systemie rekuperacji). Budynek pasywny nie potrzebuje konwencjonalnych grzejników, a niezbędna ilość ciepła jest dostarczana przez dogrzewanie powietrza wentylacyjnego (Węglarz, Stępień, 2011).

Domy pasywne już od ponad 20 lat powstają w Niemczech, Austrii oraz innych krajach Europy Zachodniej. Budynek, aby mógł zostać uznany za pasywny, zwyczajowo w Europie musi uzyskać certyfikat niemieckiego Instytutu Domów Pasywnych w Darmstadt - instytucji sprawującej nadzór nad zachowaniem standardów pasywności, prowadzonej przez twórcę idei domu pasywnego, prof. Wolfganga Feista. Należy nadmienić, iż certyfikacja wiąże się z dodatkowymi kosztami, lecz daje gwarancję na określoną ilość energii, jaką dom będzie zużywał w przyszłości.

Z punktu widzenia korzyści ochrony środowiska domy energooszczędne, a zwłaszcza pasywne, przez ograniczone do minimum zapotrzebowanie na energię mają walor niezaprzeczalny. Korzyść ekonomiczna z punktu widzenia użytkownika także jest oczywista, jednakże odczuwalna dopiero po dłuższym czasie. Według informacji zasięgniętych w biurach projektowych oraz zawartych w literaturze przedmiotu (Węglarz, Stępień, 2011) budowa domu pasywnego kosztuje w Polsce o około 20\% więcej w porównaniu z budową domu tradycyjnego. Tak więc użytkownik może liczyć na zwrot dodatkowo poniesionych kosztów dopiero po kilkunastu latach najwcześniej. W wypadku domu energooszczędnego dodatkowe nakłady są niższe i ich zwrot następuje szybciej, lecz późniejsze zyski na oszczędzaniu energii są mniejsze niż w przypadku domu pasywnego. Dla porównania, w Danii koszt budowy domu pasywnego w stosunku do budowy domu tradycyjnego jest wyższy zaledwie o 4\% i taka inwestycja zwraca się po około 6 latach, a potem generuje już tylko oszczędności energetyczne, a co za tym idzie - ekonomiczne i środowiska naturalnego (tab. 2).

Tab. 2. Zestawienie kosztów i zysków dla domu energooszczędnego i domu pasywnego

\begin{tabular}{|l|c|c|}
\hline \multicolumn{1}{|c|}{ Koszty/zyski } & Dom energooszczędny & Dom pasywny \\
\hline Dodatkowe koszty budowy & kilka procent & $24 \%$ \\
\hline Zmniejszenie kosztów ogrzewania & trzykrotne & min. ośmiokrotne \\
\hline Zwrot dodatkowych kosztów budowy & kilka lat & kilkanaście lat \\
\hline
\end{tabular}

Źródło: informacje pochodzące z biur projektowych. 
W Polsce powszechnym błędem jest kalkulowanie ceny budynku tylko jako kosztów jego zbudowania, a przywiązywanie relatywnie niewielkiego znaczenia do kosztów eksploatacji. Wobec rosnących kosztów energii budownictwo energooszczędne i pasywne wydaje się jedyną alternatywą, która dostrzeżona została w krajach Europy Zachodniej już dawno temu. Przykładowo, w Austrii, w niektórych landach stosuje się tylko i wyłącznie budownictwo pasywne. Właśnie w tym państwie opracowano ogólnokrajowy program przebudowy obiektów zgodnie ze standardami pasywności, co wraz ze zwiększonym wykorzystaniem energii ze źródeł odnawialnych uczyni kraj niezależnym od paliw kopalnych oraz importu energii (Węglarz, Stępień, 2011).

Podsumowując, domy energooszczędne i pasywne mogą być tańsze, lecz tylko w dłuższej perspektywie czasowej, gdy dodatkowe koszty budowy zostaną zwrócone. Jest to od dawna możliwe w Europie Zachodniej. W warunkach polskich czas potrzebny na zwrot poniesionych kosztów jest ciągle długi, co wynika z wysokich kosztów budowy takich domów, będący następstwem ograniczonych możliwości technologicznych, warunków klimatycznych oraz niedostatecznych instrumentów dofinansowania, aby przeciętny inwestor czy użytkownik rozważał budowę takiego domu w aspekcie ekonomicznych oszczędności. Jak dotąd jest to modny wybór dla zamożniejszych klientów. Jednakże w obliczu rosnących kosztów uzyskania energii, a z drugiej strony - postępu technologicznego, stanowi on nieuniknioną drogę rozwoju budownictwa, śladem doświadczeń zachodnich. W Polsce, już od 1 stycznia 2009 r., niemal każdy, zarówno powstający, jak i remontowany budynek i lokal mieszkalny, budynek zamieszkania zbiorowego czy też budynek użyteczności publicznej, musi legitymować się świadectwem energetycznym (Rozporządzenie... Dz.U. z 2008 r. nr 201, poz. 1240). We wszystkich krajach unijnych do końca 2020 r. wszystkie nowe budynki będą musiały mieć niemal zerowe zużycie energetyczne (Dyrektywa 2002/91/UE; Dyrektywa 2010/31/UE).

Aby dom energooszczędny był naprawdę tani z punktu widzenia przeciętnego polskiego obywatela, musiałby spełnić nie tylko warunek ekonomicznej eksploatacji, ale także niższych od przeciętnych kosztów budowy. Takim oczekiwaniom wyjść może naprzeciw nowoczesna praktyka oparta na wiedzy, której towarzyszy odwaga przedsiębiorców i użytkowników w eksperymentowaniu z nowymi materiałami i technologiami. Temu zagadnieniu poświęcona jest poniższa część niniejszego artykułu.

\section{Innowacyjna technologia versus dom tradycyjny versus dotychczasowe budownictwo energooszczędne i pasywne}

W polskich realiach wysokich kosztów budowy, utrudnionego kredytowania zakupu mieszkań i rosnących kosztów eksploatacji mieszkań konieczne staje się poszukiwanie alternatywnych w stosunku do tradycyjnych, a uwzględniających nowoczesne, a więc energooszczędne lub wręcz pasywne technologie, nowych rozwiązań niosących ze sobą oszczędności finansowe na obu etapach: powstania i użytkowania budynków. Nowoczesną technologię budowania domów łączących oba aspekty: taniej budowy i taniej eksploatacji opracowała małopolska kadra architektów i konstruktorów we współpracy z przedsiębiorcami branży budowlanej. Innowacyjność przedsięwzięcia wyraża się w technologii wznoszenia ścian, w której konstrukcja budynku stanowi jednocześnie izolację termiczną. Ściany budynku wykonane są z neoporu (spienionego polistyrenu), czyli nowoczesnego materiału izolacyjnego, będącego kolejną fazą rozwoju styropianu. Jest to styropian o wyjątkowo dobrych warunkach termoizolacyjnych. Dotychczas spieniony polistyren wykorzystywany był jedynie jako materiał izolacyjny. Po dokonaniu odpowiednich obliczeń konstruktorskich okazało się, iż można go zastosować, przy specjalnym kształtowaniu, do celów konstrukcyjnych. Gotowe elementy 
ścian domów wycinane są z dużych bloków neoporu już w fabryce i następnie transportowane na teren budowy, gdzie są składane i klejone, tworząc sztywną bryłę domu (ryc. 5 i 6 ). Powiązanie budynku z fundamentem zapewnia zatopiona w tynku zewnętrznym siatka poliuretanowa, zakotwiczona w płycie fundamentowej. Siatka oplata cały budynek, tworząc bardzo wytrzymałą powłokę, która wspomaga ogólną stateczność budynku oraz wytrzymałość elementów prefabrykowanych na ściskanie, tworząc dodatkowy zapas nośności. W omawianej technologii charakterystyczne jest wykorzystanie łuków, które przez powielenie tworzą sklepienia kolebkowe, znane już sprzed XX w. p.n.e., a sprowadzające składowe sił powstające w konstrukcji przekrycia do sił ściskających działających na ściany. Podstawowe obciążenia wywołujące stany naprężenia zredukowane są do prostych sił ściskających (Repelewicz, 2011).

Ryc. 5. Schemat konstrukcji budynku z prefabrykowanych bloków ze spienionego polistyrenu (neoporu)
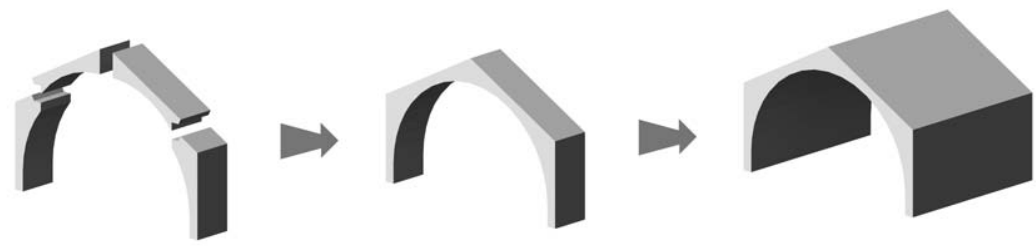

Źródło: M3-System.

Ryc. 6. Przykłady form budynków z prefabrykowanych bloków ze spienionego polistyrenu (neoporu)
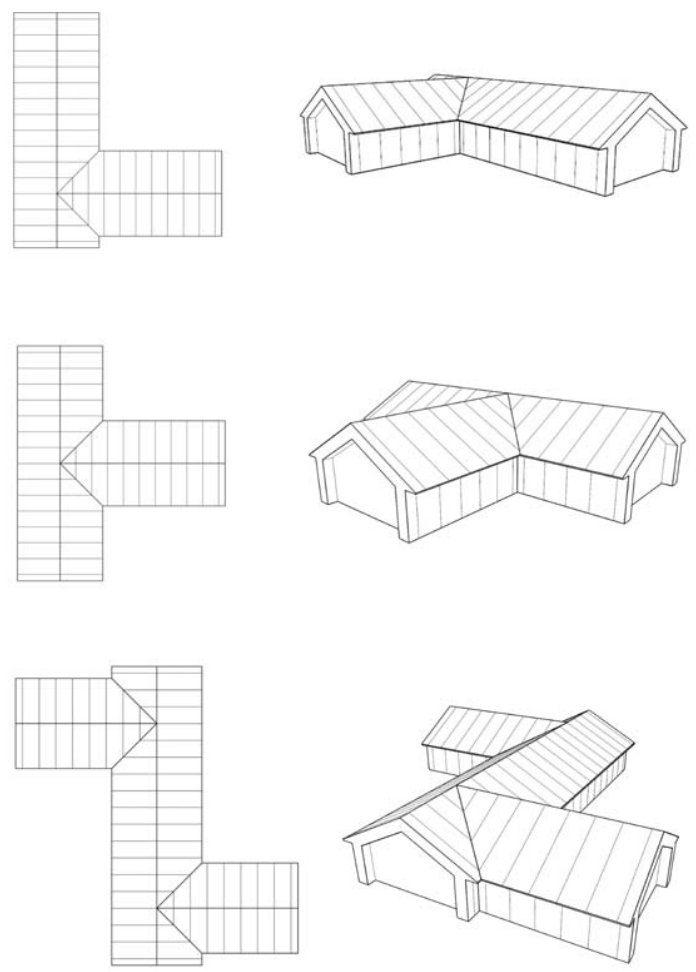

Źródło: M3-System. 
Oszczędności związane z budową obiektów z neoporu są wielorakie i wykraczają poza aspekt czysto ekonomiczny. Należą do nich:

1. oszczędności finansowe na etapie projektowania - projekty są proste, standardowe (oparte na możliwościach kształtowania neoporu), a więc cena projektu jest niższa od indywidualnego projektu domu tradycyjnego;

2. oszczędności finansowe (optymalizacja kosztów) na etapie wznoszenia budynku:

a) wykorzystanie jednego rodzaju materiału zarówno do konstrukcji, jak i izolacji wiąże się ze znacznie niższymi kosztami materiałów i robocizny,

b) zastosowanie formy monobloków eliminuje wykonanie niektórych elementów konstrukcyjnych, przede wszystkim więźby dachowej (monobloki od razu tworzą sklepienie),

c) ze względu na lekkość materiału konstrukcyjnego eliminuje się użycie dźwigów i drogiego transportu,

d) domy posadowione są na płycie fundamentowej, co eliminuje drogie roboty ziemne, a daje dodatkowe możliwości - domy z neoporu można stawiać nawet na gruntach o gorszych parametrach geotechnicznych, nieodpowiednich dla tradycyjnych technologii;

3. korzyści czasowe procesu budowy - ze względu na zastosowanie elementów wielkogabarytowych budowa domu trwa znacznie krócej niż zazwyczaj, zaledwie 2-3 miesiące do stanu ,pod klucz";

4. oszczędności finansowe na etapie użytkowania - małe straty energii służącej do ogrzania domu - wytworzone ciepło nie wnika w ściany, dom ogrzewa się szybko, dodatkowo można zastosować system rekuperacji powietrza, zamiast tradycyjnej wentylacji grawitacyjnej, który oszczędza energię;

5. korzyści dla środowiska naturalnego - przez ograniczone zużycie energii zmniejszona zostaje emisja gazów do otoczenia.

Według szacunków firmy wykonującej elementy konstrukcyjne z neoporu M3-System z Brzeska oraz pracowni projektowej Archisystem z Krakowa, budowa obiektu w tej technologii jest o połowę tańsza od budowy tradycyjnego domu. Ze względu na specjalne właściwości neoporu oraz opcjonalne zastosowanie rekuperacji powietrza, ilość energii zużytej do ogrzania domu może być niższa nawet do $85 \% \mathrm{w}$ porównaniu z tradycyjnym domem, co pozwala wykorzystać tę technologię do budowy domu energooszczędnego lub nawet pasywnego, w cenie nieprzekraczającej kosztów budowy domu tradycyjnego.

W omawianej technologii powstawać mogą nie tylko budynki mieszkalne, lecz również niewielkie obiekty użyteczności publicznej, np. biura, przedszkola, sklepy, kawiarnie. Dotychczas w tej nowatorskiej technologii powstało kilkanaście obiektów: budynek biurowy w Brzesku (całość budowy od momentu opuszczenia prefabrykatów z fabryki do zamknięcia obiektu trwała 6 tygodni) i Jarosławiu oraz domy jednorodzinne w Wieliczce, Niepołomicach i Michałowicach koło Krakowa (fot. 1, fot. 2). Aktualnie stawianych jest kilka domów jednorodzinnych w Małopolsce, na Śląsku oraz pod Warszawą. Innowacyjna technologia cieszy się zainteresowaniem w Austrii, Niemczech, w krajach arabskich oraz Meksyku i Brazylii, gdzie prowadzone są rozmowy odnośnie przyszłych realizacji.

System budowy obiektów z neoporu został opracowany przez konstruktorów i zgłoszony do urzędu patentowego. Materiał wykorzystywany do konstrukcji i zarazem izolacji jest produktem firmy „Basf” i posiada wszelkie atesty, m.in. świadectwo Instytutu Techniki Budowlanej. Jednakże pomysłodawcy opisanej nowatorskiej metody wznoszenia domów ze spienionego polistyrenu wskazują na niedostatek możliwości testowania tego rodzaju innowacji 
Fot. 1. Etap konstrukcji domu z prefabrykowanych bloków ze spienionego polistyrenu (neoporu)

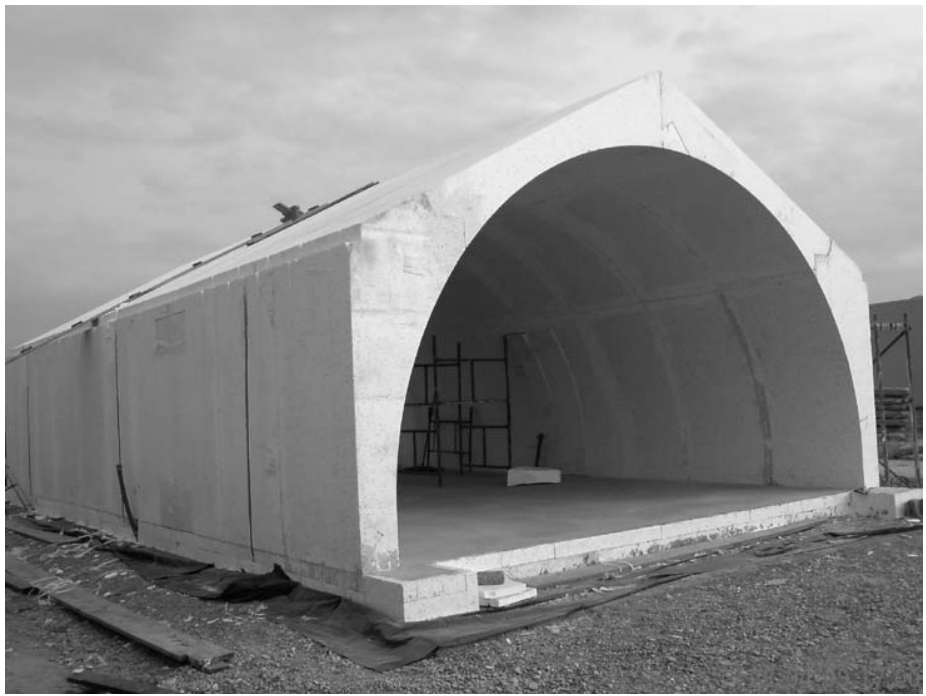

Źródło: M3-System.

Fot. 2. Przykład realizacji domu jednorodzinnego z prefabrykowanych bloków ze spienionego polistyrenu (neoporu), Wieliczka koło Krakowa

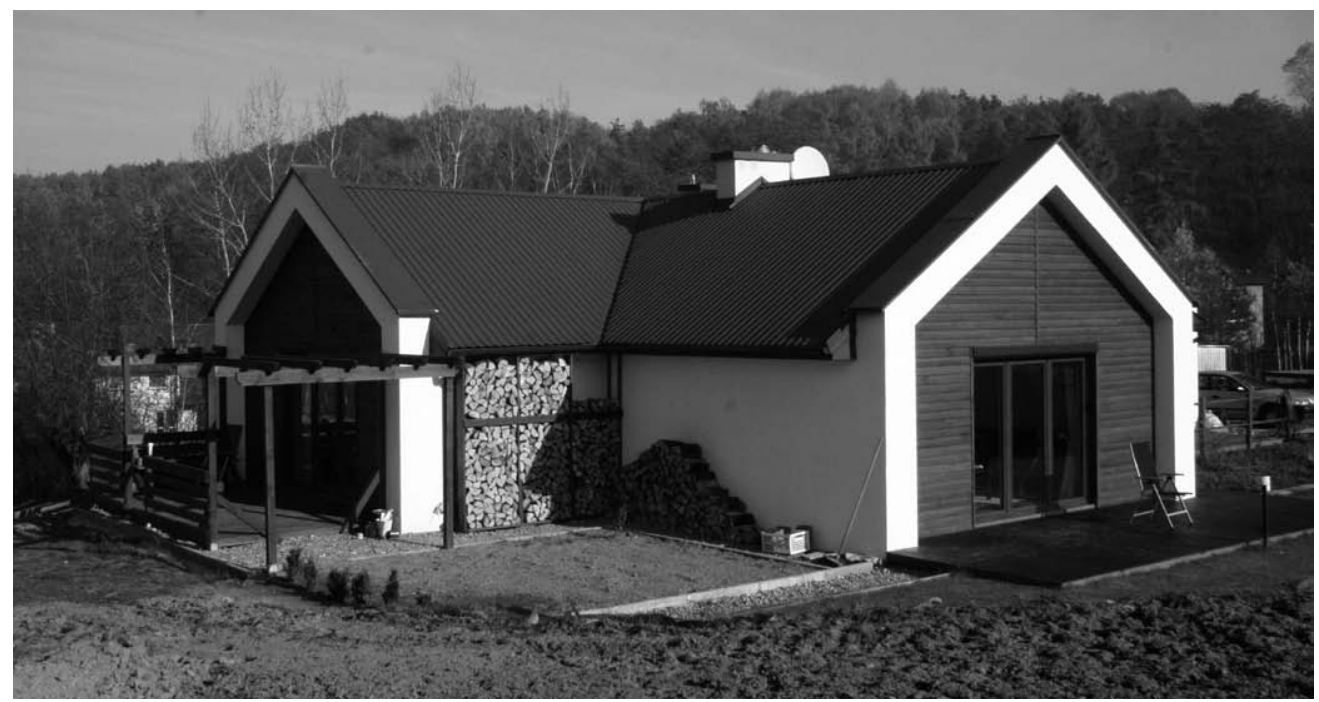

Źródło: M3-System.

w polskich realiach i postulują konieczność współpracy praktyków, tj. producentów, konstruktorów i projektantów ze środowiskiem naukowym w celach szerszego udostępnienia zaplecza naukowo-badawczego i pomocy przy weryfikacji oraz wdrażaniu nowatorskich pomysłów. W takie zapotrzebowanie wpisuje się doskonale inicjatywa powstania w naj- 
bliższej przyszłości Małopolskiego Laboratorium Budownictwa Pasywnego (MLBP) przy Politechnice Krakowskiej. Celem przedsięwzięcia jest m.in. stworzenie zaplecza badawczo-rozwojowego do badań, oceny oraz wdrażania nowoczesnych rozwiązań technologicznych, materiałowych, konstrukcyjnych i instalacyjnych dla tego rodzaju budownictwa. Samorząd województwa małopolskiego przeznaczył na projekt MLBP 3,5 mln euro (Fedorak-Cisak, Furtak, 2012). Laboratorium będzie prowadziło badania in situ, które w okresie początkowym będą miały charakter non profit. Staną się więc znaczącą pomocą dla przedsięwzięć takich, jak opisane w niniejszym opracowaniu. Firmy kreujące budowę domów z neoporu jako jedne z pierwszych wyraziły chęć współpracy z MLBP. Przyszła współpraca obu środowisk oraz przede wszystkim rozwój opisanego pomysłu budowy tanich domów z neooporu będzie przez Autorkę monitorowany, a spostrzeżenia znajdą swoje miejsce w przyszłych publikacjach.

\section{Zakończenie}

Nowatorska technologia wznoszenia domów ze spienionego polistyrenu, zwanego neoporem, jest doskonałą alternatywą dla drogich i nieekonomicznych domów tradycyjnych oraz jeszcze droższych w budowie, choć ekonomicznych w użytkowaniu, domów energooszczędnych lub pasywnych. Stanowi przykład owocnych poszukiwań nowych rozwiązań technologicznych, których celem jest uzyskanie oszczędności w procesie budowy. Oszczędności takie wymusza z jednej strony kryzys gospodarczy, a z drugiej strony - polityka unijna, wprowadzająca sukcesywnie w krajach członkowskich jako standard budownictwo niskoenergertyczne, związane ze specyficznymi wymogami materiałowymi i konstruktorskimi, generującymi jak dotąd dodatkowe koszty.

Wdrożenie na szerszą skalę omawianej technologii wymaga pokonania bariery mentalnej w postaci obaw przed nowością, uprzedzeń do mieszkania „w styropianie” oraz przyjęcia pewnych kompromisów, wynikających z ograniczeń dotyczących gabarytów i kształtowania formy - budynki powstające w tym systemie mogą być jednopoziomowe (lub ewentualnie dwupoziomowe, co podnosi jednak koszty budowy), a ich kształt podporządkowany jest elementom wielkogabarytowym, ograniczającym zróżnicowanie formy. Jednakże szala pozytywnych aspektów i barier do pokonania zdecydowanie przechyla się na korzyść tych pierwszych. Z pewnością w przyszłości coraz częściej będzie można napotkać w polskim krajobrazie budynki powstałe w omawianej technologii lub wykorzystujące podobne rozwiązania. W niniejszym opracowaniu zaprezentowano doskonały przykład próby przezwyciężania kryzysu w budownictwie mieszkaniowym od strony technologicznych rozwiązań - kryzys rodzi potrzebę działań innowacyjnych.

\section{Literatura}

Fedorak-Cisak, M., Furtak, M. (2012). Małopolskie laboratorium budownictwa pasywnego, Czasopismo Techniczne, Budownictwo, 3(109).

Gorzelak, G. (2009). Geografia polskiego kryzysu. Kryzys peryferii czy peryferia kryzysu? Warszawa: Regional Studies Association - Sekcja Polska.

Kasperkiewicz, K. (2005). Wybrane zagadnienia oceny i projektowania energooszczędnych budynków mieszkalnych, Prace Instytutu Techniki Budowlanej, 2 (134).

Kozik, R., Starzyk, E. (2011). Wpływ światowego kryzysu gospodarczego na polski rynek zamówień publicznych na roboty budowlane. Budownictwo i inżynieria środowiska, 2.

Rachwał, T. (2011). Wpływ kryzysu na zmiany produkcji przemysłowej w Polsce, Prace Komisji Geografii Przemystu Polskiego Towarzystwa Geograficznego, 17, 99-113. 
Repelewicz, M. (2011). Styropian jako materiał konstrukcyjny, Czasopismo Techniczne, Architektura, 11 (108).

Węglarz, A., Stępień, R. (2011). Dom pasywny. Warszawa: Instytut na rzecz Ekorozwoju, przy współpracy Krajowej Agencji Poszanowania Energii S.A.

\section{Źródla statystyczne i prawne}

Dyrektywa Parlamentu Europejskiego i Rady 2002/91/UE z dnia 16 grudnia 2002 r. w sprawie charakterystyki energetycznej budynków.

Dyrektywa Parlamentu Europejskiego i Rady 2010/31/UE z dnia 19 maja 2010 r. w sprawie charakterystyki energetycznej budynków.

GUS (2012, 15 października), Informacje bieżace, Warszawa.

Housing Europe Review, The Nuts and Bolts of European Social Housing Systems, 2012, 2011, CECODHAS Housing Europe's Observatory, Brussels.

Rozporzadzenie Ministra Infrastruktury z 6 listopada 2008 r. zmieniajace rozporzadzenie w sprawie warunków technicznych, jakim powinny odpowiadać budynki i ich usytuowanie (Dz.U. nr 201, poz. 1238 z późn. zm.).

Rozporządzenie Ministra Infrastruktury z 6 listopada 2008 r. w sprawie metodologii obliczania charakterystyki energetycznej budynku stanowiacej samodzielna całość techniczno-użytkowa oraz sposobu sporządzania świadectw i ich charakterystyki energetycznej (Dz.U. nr 201, poz. 1240).

\section{Źródła internetowe}

www.archisystem.pl, www.domy-pasywne.pl, www.m3system.pl, www.passiv.de, www.reas.pl

Monika Plaziak, dr, adiunkt, Uniwersytet Pedagogiczny, Instytut Geografii, Zakład Przedsiębiorczości i Gospodarki Przestrzennej.

Zainteresowania badawcze Autorki dotyczą zagadnień gospodarki przestrzennej w kontekście czynników lokalizacji przedsiębiorstw, szczególnie czynnika personalnego. Prace badawcze odnoszą się również do zagadnień współpracy jednostek naukowych i badawczo-rozwojowych z sektorem MŚP, zwłaszcza w zakresie wdrażania nowych technologii i materiałów, w tym dotyczących budownictwa energooszczędnego i pasywnego. Ponadto, autorka zajmuje się problematyką poziomu i jakości życia ludności, ze szczególnym uwzględnieniem małych i średnich miast Polski oraz miast postsocjalistycznych.

Monika Plaziak, PhD, Pedagogical University of Cracow, Institute of Geography, Department of Entrepreneurship and Spatial Management.

The author's research interests concern issues of spatial development in the context of location factors of enterprises, with special attention given to the personal factor. Research work also focuses on issues of cooperation between scientific and researchdevelopment organizations, within the sector of small and medium-sized enterprises, especially in the area of implementing new technologies and materials, related to energy-efficient and passive buildings. Additionally, the author analyses issues of the level and quality of life, with particular reference to small and medium-sized towns in Poland, as well as post-socialist towns.

Adres/Address: Uniwersytet Pedagogiczny, Instytut Geografii

Zakład Przedsiębiorczości i Gospodarki Przestrzennej

ul. Podchorążych 2, 30-084 Kraków

e-mail:mplaziak@up.krakow.pl 